\title{
A LESSON FOR SUNFLOWER: THE SOYBEAN EXPERIENCE OF THE BLACK SEA REGION
}

\author{
Kara, S.M. , Uyanik, M.
}

Ordu University, Faculty of Agriculture, Department of Field Crops, 52000 , Ordu, Turkey

Received: April 10, 2010

Accepted: August 10, 2010

\section{SUMMARY}

Oilseeds are one of the most valuable crops in Turkey's agriculture and economy as they are the most important source of vegetable oil, feed for livestock and, as of recently, biodiesel feedstock. At the present time, Turkey cannot even meet its own demand for oilseeds, and this problem stems mainly from a lack of planning in the production phase. At present, more than half of the country's need for oil is s met by imports and the import value of crude vegetable oil and oilseed crops is the second largest figure in the country's total exchange expenditures, trailing only petroleum products.

In the last two decades, although the total oilseeds production has increased nearly $20 \%$, the area planted to oilseeds has gone down by $12 \%$. Among oilseeds, soybean has been hit the hardest, as the area planted to the crop and its production decreased by $80 \%$ and $68 \%$, respectively. In the Black Sea region, including the Samsun and Ordu provinces, which used to be the country's largest soybean producer, soybean areas and production have also decreased drastically. The soybean acreage and production in the Samsun province have dropped by $60 \%$ and $18 \%$, respectively. Worse still, in the Ordu province, where the country's first soybean oil factory was set up in 1965, soybean is not grown anymore. Farmers in the two provinces have started gravitating mostly towards hazelnut production, resulting in a nine-fold and two-fold increase in the Samsun and Ordu provinces, respectively.

Sunflower, the major oilseed crop of Turkey, currently provides approximately $50 \%$ of the country's total oilseed supply. Over the years, sunflower production in Turkey has followed an ever-fluctuating course. The situation is even worse in the Central Black Sea region including Samsun, Çorum and Amasya provinces, where sunflower area have decreased by $54 \%, 53 \%$ and $72 \%$, respectively. On the other hand, the self-sufficiency ratio in sunflower consumption has decreased from $70 \%$ in 2000 to $38 \%$ in 2007 . The excessive decrease in the self-sufficiency ratio should be regarded as an alarm bell for sunflower and must be taken seriously without delay if the country does not want to play out the same tragic scenario as in the case of soybean. It should always be kept in mind that strategic planning for the future in most cases depends on past history.

Key words: oil consumption, oilseeds, production planning, soybean, sunflower

* Corresponding author: e-mail: smkara58@hotmail.com 


\section{INTRODUCTION}

Turkey, endowed with a wide range of climatic conditions and rich natural resources, has a high agricultural potential, which enables the cultivation of several crop species. However, its agricultural sector has never reached its potential, mainly because of inefficient and improper agricultural policies that have been adopted and implemented in the country for years. Oilseeds are one of the most valuable crops in Turkey's agriculture and economy, as they are the most important source of vegetable oil, feed for livestock, and, as of recently, biodiesel feedstock. Currently, Turkey's demand for oilseeds is quite strong and will continue to grow exponentially in the future. Despite a substantial amount of suitable land, however, the country's oilseed production has not even been able to meet the domestic demand for vegetable oil. At the present time, Turkey cannot even meet its own demand for oilseeds, and this problem stems mainly from a lack of planning in the production phase. Turkey is, thus, a net importer of oilseed products in international trade. At present, more than half of the country's need for oil is s met by imports and the import value of crude vegetable oil and oilseed crops is the second largest figure in the country's total exchange expenditures, trailing only petroleum products (Kolsarici et al., 2005).

The lack of a stable policy aimed at fostering self sufficiency in general has caused oilseeds production over the years to follow an ever-fluctuating course (Anonymous, 2008). In the last two decades, although the total oilseeds production has increased nearly $20 \%$, the area planted to oilseeds has gone down by $12 \%$ (Table 1). Domestic oilseed production contributes only about 2 million tons a year and the country has to import more than half of its need to fill the gap. Until 1985, Turkey covered $75 \%$ of its vegetable oil needs with domestic production, but this figure has since decreased to $30 \%$ (Arioglu et al., 2010). Total crude vegetable oil imports rose steadily from 150,000 tons in the 1980 s to 575,000 tons in 1990 and then soared to $1,243,000$ tons in 2007 with a total value of nearly $\$ 700$ billion (Buyuksahin, 2008). Turkey has a total crude oil processing capacity of over 3 million tons per year, more than two thirds of which is used to produce liquid oils. Despite this high potential, the capacity utilization rate is rather low, around $50 \%$.

In order of the amount of current output, the major oilseed crops in Turkey are cotton, sunflower, peanut, soybean, sesame, and, to some extent, rapeseed. During the 1991-2008 period, the area planted to cotton and sesame decreased by $17.3 \%$ and $66 \%$, respectively, while the acreage sown to sunflower increased by $2.2 \%$. During the same period, the self-sufficiency ratios in total consumption of sunflower, rapeseed and soybean fluctuated between 38.0 and $84.8 \%, 0.8$ and 30.4 , and 1.5 and 6.7, respectively. Among oilseeds, soybean has been hit the hardest, as the area planted to the crop and its production decreased by $80 \%$ and $68 \%$, respectively (Anonymous, 2008). The downturn in the Black Sea region, once the country's main soybean supplier, is currently at its very worst in particular. The purpose of 
this paper was to provide a lesson for sunflower from the soybean experience of the Black Sea region by presenting a brief history of soybean production.

Table 1: Planted area and production for total oilseeds, soybean and sunflower in Turkey.

\begin{tabular}{lcccccc}
\hline \multirow{2}{*}{ Year } & \multicolumn{3}{l}{ Total oilseeds } & \multicolumn{3}{c}{ Soybean } \\
\cline { 2 - 6 } & Area & Production & Area & Production & Area & Production \\
\cline { 2 - 7 } & $(1000 \mathrm{ha})$ & $(1000 \mathrm{t})$ & $(1000 \mathrm{ha})$ & $(1000)$ & $(1000 \mathrm{ha})$ & $(1000 \mathrm{t})$ \\
\hline 1991 & 1368.5 & 1933.9 & 49.5 & 110.0 & 567.5 & 800.0 \\
1992 & 1429.9 & 2061.1 & 46.0 & 110.0 & 613.0 & 950.0 \\
1993 & 1312.5 & 1882.1 & 26.8 & 63.0 & 597.0 & 815.0 \\
1994 & 1340.8 & 1859.1 & 29.0 & 70.0 & 586.0 & 740.0 \\
1995 & 1537.1 & 2391.7 & 31.0 & 75.0 & 585.0 & 900.0 \\
1996 & 1462.1 & 2165.6 & 20.5 & 50.0 & 575.0 & 780.0 \\
1997 & 1432.4 & 2254.8 & 19.0 & 40.0 & 560.0 & 900.0 \\
1998 & 1520.1 & 2407.4 & 23.0 & 60.0 & 586.0 & 860.0 \\
1999 & 1505.6 & 2308.6 & 24.0 & 66.0 & 595.0 & 950.0 \\
2000 & 1319.2 & 2253.4 & 15.0 & 44.5 & 542.0 & 800.0 \\
2001 & 1335.8 & 2171.3 & 17.0 & 50.0 & 510.0 & 650.0 \\
2002 & 1429.8 & 2514.8 & 25.5 & 75.0 & 550.0 & 850.0 \\
2003 & 1384.7 & 2387.9 & 27.0 & 85.0 & 545.0 & 800.0 \\
2004 & 1305.8 & 2501.2 & 14.0 & 50.0 & 550.0 & 900.0 \\
2005 & 1216.2 & 2421.3 & 8.6 & 29.0 & 566.0 & 975.0 \\
2006 & 1298.7 & 2789.1 & 11.9 & 47.3 & 585.4 & 1118.0 \\
2007 & 1186.4 & 2352.3 & 8.7 & 30.7 & 554.6 & 854.4 \\
2008 & 1192.1 & 2311.4 & 9.4 & 34.5 & 580.0 & 992.0 \\
\hline
\end{tabular}

\section{The Perspective of Soybean Production in Turkey}

The earliest known cultivation of soybean in Turkey dates back to the 1940s and was performed under rain-fed conditions in a limited area along the east side of the Black Sea coast (Karacaoglu, 1984). Therefore, soybean got off to a late start in Turkey and production was insignificant until the mid-1970s. Large-scale production of soybean began in Turkey during the 1980s and increased rapidly thereafter, as the Ministry of Agriculture encouraged the farmers to produce soybean as a secondary crop, mostly in the irrigated areas of the Mediterranean and Aegean regions. This intervention had an immediate impact and did much to increase the area harvested and production. Consequently, soybean production grew from 3,000 t in 1979 to $15,000 \mathrm{t}$ in 1981 and reached its maximum of $250,000 \mathrm{t}$ in 1987. After that, however, it took a downturn and began to decrease steadily until it finally reached 44,500 t in 2000 and 34,500 t in 2008 (Table 1). Improper and/or insufficient agricultural policies and the growing demand from the oil and feed industries, along with the low prices in the international market that promoted soybean importation, played a major role in this decrease (Ustun and Gümüscü, 2007). At the present time, the total soybean need of Turkey has reached around 2 million tons, 
but only $2 \%$ of this quantity is supplied by domestic production. Currently, the Cukurova region, including Adana, Mersin and Osmaniye provinces, provides nearly $74 \%$ of the total soybean production, while the Samsun province accounts for $21 \%$.

In the Black Sea region, once the country's largest soybean producer, a growing number of farmers have stopped planting soybeans due to low profit margins resulting mostly from the pricing and marketing problems involved. As a result, soybean areas and production in the region including Samsun and Ordu provinces have decreased drastically. In the last two decades, soybean areas and production in the Samsun province have dropped by $60 \%$ and $18 \%$, respectively. Worse still, in the Ordu province, where the country's first soybean oil factory was set up in 1965 , soybean is not grown anymore. Farmers in the two provinces have started gravitating mostly towards hazelnut production, resulting in a nine-fold and two-fold increase in the Samsun and Ordu provinces, respectively.

Hazelnut production, with a multifunctional aspect, is a key factor in maintaining sustainability in rural areas of the Black Sea region. The disappearance of nut plantations, particularly in less favorable areas, could have significant environmental, rural, social and economic consequences. Nut production is practically no longer competitive in places like the Ordu province and in the eastern part of the Samsun province to some extent. Meanwhile, due to the socio-economic importance of the crop, the Turkish government has been providing funds for hazelnut prices for quite some time. In consequence of historically high support prices, hazelnut areas and production expanded exponentially (Gonenc et al., 2006). As a result of all these factors, it is now too late and difficult to re-establish soybean in the areas seized by hazelnut.

\section{A Glance at Sunflower Production in Turkey}

Sunflower, the major oilseed crop of Turkey, currently provides approximately $50 \%$ of the country's total oilseed supply. Turkey is the world's eleventh largest sunflower producer with a production of approximately 1 million tons in 2008, providing $2.7 \%$ of the world total (Anonymous, 2008). When sunflower cultivation is analyzed by region, most of the sunflower typically comes from the Thracian region, where sunflower is the most important source of income. The Thracian region provides nearly $75 \%$ of both the sunflower area and production, followed by the Marmara and the Black Sea regions with a share of $10 \%$ each.

Over the years, sunflower production in Turkey has followed a steady or fluctuating course, implying that an efficient sunflower production policy has not been mastered. In 1991, sunflower was planted on 567,500 hectares with 800,000 tons of production, while in 2008 it was planted on 580,000 hectares of land producing 992,000 tons (Table 1). The self-sufficiency ratio in the sunflower supply has dropped from $70 \%$ in 2000 to $38 \%$ in 2007 . The situation is even worse in the Central Black Sea region including Samsun, Corum and Amasya provinces, where sun- 
flower area has decreased by 54\%, 53\% and $72 \%$, respectively, in the last two decades (Table 2). On the other hand, hazelnut areas in Samsun and the total corn area (grain and silage) in Corum and Amasya provinces has approximately increased by $183 \%, 400 \%$, and $200 \%$, respectively. Similarly, the sunflower area has gone down by $54 \%$ in the Sakarya province, but the decrease in the Kocaeli province has been quite striking, from 14,200 hectares in 1991 to only 900 in 2008 (Table 2). In the meantime, hazelnut production in these two provinces has increased almost three-fold.

Although the sunflower price has been more or less stable in recent years, the cost of sunflower inputs has kept increasing in Turkey. This increase influenced both the sunflower acreage and sunflower yield performance due to a lower use of inputs (Semerci et al., 2007). Sunflower has a low profitability rate in both dry and irrigated conditions and thus brings a lower income than wheat, corn or paddy rice. The price relationship between sunflower and other alternative crops is a key factor that affects the farmers' crop choices. In the 1980-2000 period, the rate of increase in the real prices of sunflower was $4.6 \%$, as opposed to $34.6 \%$ for wheat and 125.3\% for sugar beet (Fidan and Ozcelik, 2003).

Table 2: Areas planted to sunflower (1000 ha) in some provinces in Turkey.

\begin{tabular}{lccccc}
\hline Year & Samsun & Amasya & Corum & Kocaeli & Sakarya \\
\hline 1991 & 17.3 & 16.7 & 13.7 & 13.7 & 5.5 \\
1992 & 17.1 & 16.1 & 15.5 & 15.5 & 3.2 \\
1993 & 15.3 & 16.4 & 15.3 & 15.3 & 3.2 \\
1994 & 14.0 & 15.1 & 15.2 & 15.2 & 2.9 \\
1995 & 14.4 & 15.4 & 13.4 & 13.4 & 3.2 \\
1996 & 12.9 & 16.6 & 12.3 & 12.3 & 3.4 \\
1997 & 9.5 & 8.4 & 11.8 & 11.8 & 4.2 \\
1998 & 10.0 & 7.2 & 13.9 & 13.9 & 4.0 \\
1999 & 9.4 & 5.9 & 14.4 & 14.4 & 8.9 \\
2000 & 8.6 & 5.5 & 10.8 & 10.8 & 7.9 \\
2001 & 8.2 & 3.8 & 8.1 & 8.1 & 4.3 \\
2002 & 7.9 & 6.9 & 11.5 & 11.5 & 4.5 \\
2003 & 7.7 & 5.3 & 9.0 & 9.0 & 3.9 \\
2004 & 9.3 & 6.3 & 6.3 & 6.3 & 3.2 \\
2005 & 7.4 & 7.1 & 7.2 & 7.2 & 3.4 \\
2006 & 8.9 & 7.1 & 7.6 & 7.6 & 3.2 \\
2007 & 7.7 & 4.8 & 5.8 & 5.8 & 2.7 \\
2008 & 8.0 & 4.7 & 6.4 & 6.4 & 3.3 \\
\hline
\end{tabular}

Even in the Thracian region, the main sunflower supplier of the country, the sunflower / wheat parity has often been lower than 2, which is one of the important factors causing a reduction in sunflower acreage. In the period between 1990 and 2005, sunflower production in the region showed an increase, because the sunflower/wheat parity was maintained at a level of over 2.5 (Semerci and Kaya, 2007). In order for sunflower production to spread, farmers should be financially assisted, input costs must be decreased, and purchasing prices must be high and disclosed 
early. Aside from achieving satisfactory input use efficiency, securing a certain price parity between sunflower and other crops (at a level of over 2.5) is an absolute must in order to get an adequate increase in sunflower production (Semerci et al., 2007).

\section{Lessons from the Past for the Future}

Taking into account Turkey's past and present oilseed outlook, it is certain that Turkey's demand for oilseeds, particularly for soybean and sunflower, is quite strong and will continue to grow exponentially in the future. Even if the domestic oilseed production increases in the few years ahead, the growing demand must be met by imports in the short term (Onurlubas and Kizilaslan, 2007). Because of the increases in population and per capita oil consumption and the growing demand from the oil and poultry feed industries, it is necessary to take all due precautions in time in order to raise oilseed production sufficiently in the long term.

The recent excessive decreases in the self-sufficiency ratio along with the declining areas and production in some provinces should be regarded as an alarm bell for sunflower and must be seriously taken into account without delay if the country does not want to play out the same tragic scenario as in the case of soybean. It should always be kept in mind that strategic planning for the future in most cases depends on past history. Future perspectives can only be gained from examining the past and applying it to the present.

\section{REFERENCES}

Anonymous, 2008. Turkiye Istatistik Kurumu. http://www.tuik.gov.trea

Arioglu, H.H., Kolsarici, O., Goksu, A.T., Gulluoglu, L., Arslan, M., Caliskan, S., Sogut T., Kurt C. and Arslanoglu, F., 2010. Yag bitkileri uretiminin artirilmasi olanaklari. TMMOB Ziraat Muhendisleri Odasi Turkiye Ziraat Mühendisligi VII. Teknik Kongresi, 11-15 Ocak 2010, Ankara, Turkey.

Buyuksahin, H., 2008. Bitkisel Yag Sanayicileri Derneginin Yag Sektörune Bakisi. Bitkisel Yemeklik Yaglar Sempozyumu. 8-10 Mayis 2008, Adana, Turkey.

Fidan, H. and Ozcelik, A., 2003. Turkiye Ekonomisi Yonunden Ayçiçeginin Onemi. Turkiye I. Yagli Tohumlar, Bitkisel Yaglar ve Teknolojileri Sempozyumu, 22-23 Mayis 2003, Istanbul, Turkey.

Gonenc, S., Tanrivermis, H. and Bulbul, M., 2006. Economic assessment of hazelnut production and the importance of supply management approaches in Turkey. Journal of Agricultural and Rural Development in the Tropics and Subtropics 107(1): 19-32.

Karacaoglu, M.,1984. SOYA. Ekonominin Sari Altini. 2. Baski, Ongun Kardesler Matbaacilik Sanayii, Ankara, Turkey.

Kolsarici, O., Gur, A., Basalma, D., Kaya, M.D. and Isler, N., 2005. Yagli tohumlu bitkiler üretimi. TMMOB Ziraat Mühendisleri Odasi Turkiye Ziraat Mühendisligi VI. Teknik Kongresi, 3-7 Ocak 2005, Ankara, Turkey.

Onurlubas, H.E. and Kizilaslan, H., 2007. Turkiye‘de Bitkisel Yag Sanayindeki Gelismeler ve Gelecege Yonelik Beklentiler. Tarimsal Ekonomi Arastirma Enstitusu, No: 157, Ankara.

Semerci, A. and Kaya, Y., 2007. Aycicegi uretiminde maliyet, parite ve uzun donem egilimleri. I.Ulusal Yagli Tohumlu Bitkiler ve Biyodizel Sempozyumu, 28-31 Mayis 2007, Samsun, Turkey.

Semerci, A., Kaya, Y. and Durak, S., 2007. Economic analysis of sunflower production in Turkey. Helia 30 (47): 105-114.

Ustun, A. and Gumuscu, G., 2007. Soya Uretimi ve Tarim Politikasi. I. Ulusal Yagli Tohumlu Bitkiler ve Biyodizel Sempozyumu, 28-31 Mayis 2007, Samsun, Turkey. 